\title{
Dukungan Suami dan Unmet Need KB Pada Wanita Pasangan Usia Subur (WPUS)
}

\author{
Dinda Tasya Nabila*, Dwi Nur'aini Nindya \\ Fakultas Kesehatan Masyarakat Universitas Indonesia \\ *Korespondensi: Dinda Tasya Nabila - dindatasya22@gmail.com
}

\begin{abstract}
Abstrak
Unmet need KB merupakan salah satu indikator dari keberhasilan program KB yang bertujuan untuk mengendalikan laju pertumbuhan penduduk di Indonesia. Pada masyarakat berbudaya patriarki, dukungan suami memiliki peran yang besar dalam menentukan keikutsertaan wanita untuk menggunakan alat kontrasepsi. Penelitian ini bertujuan untuk menjelaskan hubungan antara dukungan suami dengan terjadinya unmet need KB pada Wanita Pasangan Usia Subur (WPUS). Sebuah studi literature review dilakukan dengan memanfaatkan database Google Scholar, NCBI, Science Direct, Biomed Central (BMC), dan Elsevier untuk menelusuri jurnal nasional dan internasional yang meneliti hubungan antara dukungan suami dengan terjadinya unmet need KB pada WPUS. Hasil review dari 14 jurnal menunjukkan bahwa dukungan suami memiliki hubungan dengan terjadinya unmet need KB pada WPUS. WPUS yang tidak mendapatkan dukungan dari suami memiliki peluang antara 2,1 sampai 100,5 kali mengalami unmet need KB lebih besar dibandingkan dengan WPUS yang mendapat dukungan dari suami. Sebagai kesimpulan, suami yang tidak memberi dukungan dapat menurunkan tingkat penggunaan kontrasepsi pada WPUS yang akan berdampak pada terjadinya peningkatan angka unmet need KB.
\end{abstract}

Kata Kunci: unmet need KB, kontrasepsi, keluarga berencana, dukungan suami, pasangan usia subur

\section{Husband's Support and Unmet Needs Family Planning in Women of Fertile Age Couples (WFAC)}

\begin{abstract}
Unmet need for family planning is an indicator of the success of the family planning program which aims to control the population growth rate in Indonesia. In a patriarchal cultured society, the support of the husband has a big role in determining the participation of women in using contraceptives. This study aims to explain the relationship between husband's support and the occurrence of unmet need for family planning in women with fertile age couples (WPUS). A literature review study was conducted using the Google Scholar database, NCBI, Science Direct, Biomed Central (BMC), and Elsevier to explore national and international journals examining the relationship between husband's support and the occurrence of unmet need for family planning in WPUS. The results of a review of 14 journals show that husband's support has a relationship with the occurrence of family planning unmet need in WPUS. WPUSs who do not get support from their husbands have a greater chance of experiencing family planning unmet need between 2.1 and 100.5 times compared to WPUSs who receive support from their husbands. In conclusion, husbands who do not provide support can reduce the level of contraceptive use in WPUS which will have an impact on the increase in the number of unmet needs for family planning.

Key Words: unmet need family planning, contraception, family planning, support from husbands, spouses of fertile
\end{abstract} age 


\section{PENDAHULUAN}

Merujuk kepada data Survei Penduduk Antar Sensus (SUPAS) 2015, Indonesia merupakan negara yang memiliki jumlah penduduk tertinggi nomor empat di dunia dengan laju pertumbuhan penduduk (LPP) pada periode 2010 - 2015 sebesar 1,43\% (1). Angka LPP tersebut masih jauh dari angka yang diperkirakan akan menurun dalam Proyeksi Penduduk Indonesia 2015 2045 yaitu sebesar 1,07\% pada periode 2015 - 2020 (2). Sementara itu, jumlah penduduk Indonesia masih akan terus mengalami peningkatan dari 269,6 juta pada 2020, menjadi 294, 1 juta di tahun 2030 dan diperkirakan akan mencapai 318,9 juta pada 2045 nanti (3).

Pemerintah telah melakukan berbagai langkah serius untuk menanggulangi peningkatan laju pertumbuhan penduduk yang terus meningkat, salah satunya yaitu melalui kebijakan Program Keluarga Berencana (KB). Program KB selain menjadi program nasional, juga menjadi salah satu target yang perlu dicapai dalam Sustainable Development Goals (SDG'S) yaitu target pemenuhan hak kesehatan seksual dan reproduksi serta sosialisasi program penurunan kelahiran yang efektif dan efisien (4). Untuk menilai keberhasilan dari program KB salah satunya dapat dilihat dari indikator angka kelahiran total (Total Fertility Rate). TFR Indonesia pada tahun
2012 sebesar 2,6 per wanita usia subur (5), kemudian menurun menjadi 2,4 pada 2017 (6), dan kembali meningkat menjadi 2,45 pada tahun 2020 (7). Walaupun demikian, angka TFR tersebut masih cukup jauh dari angka yang ditargetkan oleh BKKBN di dalam RENSTRA BKKBN 2020-2024 yaitu sebesar 2,1 per wanita usia subur (3).

Keberhasilan program KB juga dapat dilihat dari indikator angka unmet need. Unmet need $\mathrm{KB}$ adalah suatu persentase yang menunjukkan kebutuhan KB yang tidak terpenuhi pada WPUS (wanita pasangan usia subur) yang aktif secara seksual namun tidak menginginkan anak, baik untuk tujuan menghentikan kelahiran (stop childbearing) maupun menunda kelahiran (delay childbearing) (3,8). Di Indonesia, angka unmet need $\mathrm{KB}$ pada tahun 2012 sebesar 11,4\% (5), kemudian menurun menjadi 10,6\% di tahun 2017 (6), dan kembali menurun pada tahun 2018 menjadi 10,14\% (9). Angka unmet need dari tahun ke tahun tersebut masih belum mencapai angka unmet need yang ditargetkan oleh BKKBN di dalam RENSTRA BKKBN 2020-2024 yaitu sebesar 7,4\% (3).

Masalah unmet need $\mathrm{KB}$ merupakan masalah yang dipengaruhi oleh banyak faktor. Sejumlah penelitian menyatakan bahwa kejadian unmet need pada wanita yang telah menikah sebagian besar disebabkan oleh faktor sosial-demografi 
$(10,11)$, keterbatasan pengetahuan terhadap alat kontrasepsi, larangan suami dan keluarga $(10,12)$ dan sulitnya akses ke layanan $\mathrm{KB}(11,12)$.

Faktor larangan suami sebagai salah satu faktor yang menyebabkan tingginya angka unmet need pada PUS didasari oleh kondisi budaya patrilineal yang dianut oleh sebagian besar masyarakat Indonesia. Budaya patrilineal tersebut secara tidak langsung telah menjadikan pria sebagai kepala keluarga sekaligus pihak yang bertanggung jawab dalam menentukan keikutsertaan wanita untuk menggunakan alat kontrasepsi. Istri yang tidak mendapatkan dukungan dari suami cenderung akan mengalami unmet need karena adanya faktor pendorong berupa dukungan suami yang mempengaruhi perilaku penggunaan kontrasepsi (13).

Penelitian yang dilakukan oleh Ainia (2018), mengungkapkan bahwa wanita usia subur (WUS) yang tidak mendapatkan dukungan dari suami akan berpeluang untuk mengalami terjadinya unmet need $\mathrm{KB}$ 4,9 kali lebih besar dibandingkan dengan WUS yang mendapatkan dukungan dari suami (14). Sementara itu, penelitian yang dilakukan oleh Yuliati, Simanjuntak, dan Oktriyanto (2019) menunjukkan hasil yang berbeda yaitu dukungan suami tidak memiliki pengaruh yang signifikan terhadap minat penggunaan alat kontrasepsi pada kelompok WUS unmet need KB (15).
Melalui permasalahan yang telah dijabarkan sebelumnya, penelitian ini bertujuan untuk menjelaskan hubungan antara dukungan suami dengan terjadinya unmet need KB pada Wanita Pasangan Usia Subur (WPUS).

\section{METODE}

Penelitian ini merupakan penelitian literature review dengan memanfaatkan jurnal nasional dan jurnal internasional berbahasa inggris melalui pencarian di lima database diantaranya yaitu Google Scholar, NCBI, Science Direct, Biomed Central (BMC), dan Elsevier. Adapun kriteria inklusi yang digunakan dalam penelitian ini adalah jurnal yang meneliti hubungan antara dukungan suami dengan kejadian unmet need $\mathrm{KB}$ pada pasangan usia subur dan memiliki tahun publikasi 10 tahun terakhir, sedangkan kriteria eksklusi yang digunakan adalah jurnal yang teksnya tidak lengkap, duplikat, tidak bisa diakses dan tidak relevan dengan topik. Adapun kata kunci yang digunakan dalam penelusuran pustaka yaitu 1) husband support, 2) unmet need for family planning, 3) couples of childbearing age, 4) quantitative study, 5) dukungan suami, 6 unmet need $\mathrm{KB}, 7$ pasangan usia subur dan 8) kuantitatif.

Total hasil temuan literatur sebanyak 2506 jurnal yang terdiri dari 1580 jurnal bahasa inggris dan 926 jurnal bahasa 
indonesia yang didapatkan dari penggunaan kata kunci. Sebanyak 1893 jurnal diantaranya dieksklusi karena tidak relevan dengan topik yang diteliti. Kemudian, dari total 613 jurnal yang tersisa, 484 jurnal diantaranya dieksklusi karena keterbatasan akses, 102 lainnya dieksklusi karena ketidaklengkapan jurnal dan 10 jurnal diantaranya duplikasi sehingga didapatkan hasil akhir sebanyak 13 jurnal (6 jurnal Bahasa Inggris dan 7 jurnal Bahasa Indonesia).

\section{HASIL}

Rincian literatur berupa judul, nama penulis, metode penelitian dan hasil penelitian dapat dilihat pada Tabel 1.

Tabel 1. Hasil Temuan Literatur

\begin{tabular}{|c|c|c|c|c|}
\hline No & Judul & $\begin{array}{l}\text { Penulis } \\
\text { (Tahun) }\end{array}$ & Metode & Hasil \\
\hline 1. & $\begin{array}{l}\text { Husband's support towards } \\
\text { unmet need family planning } \\
\text { incidence on couples of } \\
\text { childbearing age in Denpasar } \\
\text { city (16) }\end{array}$ & $\begin{array}{c}\text { Wayan dan } \\
\text { Kadek } \\
(2020)\end{array}$ & $\begin{array}{c}\text { Cross } \\
\text { sectional }\end{array}$ & $\begin{array}{l}\text { WUS yang tidak mendapatkan } \\
\text { dukungan dari suami akan berpeluang } \\
\text { untuk mengalami terjadinya unmet } \\
\text { need KB } 11 \text { kali lebih besar } \\
\text { dibandingkan dengan WUS yang } \\
\text { mendapatkan dukungan dari suami. }\end{array}$ \\
\hline 2. & $\begin{array}{l}\text { Determinan Kejadian Unmet } \\
\text { Need KB Di Wilayah Kerja } \\
\text { Puskesmas Peukan Bada } \\
\text { Kabupaten Aceh Besar Tahun } \\
2019 \text { (17) }\end{array}$ & $\begin{array}{c}\text { Safitri dan } \\
\text { Kana (2019) }\end{array}$ & $\begin{array}{c}\text { Cross } \\
\text { sectional }\end{array}$ & $\begin{array}{l}\text { WUS yang tidak mendapatkan } \\
\text { dukungan dari suami akan berpeluang } \\
\text { untuk mengalami terjadinya unmet } \\
\text { need KB } 12,6 \text { kali lebih besar } \\
\text { dibandingkan dengan WUS yang } \\
\text { mendapatkan dukungan dari suami. }\end{array}$ \\
\hline 3. & $\begin{array}{l}\text { Levels, trends and reasons for } \\
\text { unmet need for family } \\
\text { planning among married } \\
\text { women in Botswana: a cross- } \\
\text { sectional study (18) }\end{array}$ & $\begin{array}{l}\text { Letamo dan } \\
\text { Navaneetham } \\
\quad(2015)\end{array}$ & $\begin{array}{c}\text { Cross } \\
\text { sectional }\end{array}$ & $\begin{array}{l}\text { WUS yang tidak mendapatkan izin } \\
\text { dari suami akan berpeluang untuk } \\
\text { mengalami terjadinya unmet need KB } \\
2,8 \text { kali lebih besar dibandingkan } \\
\text { dengan WUS yang mendapatkan izin } \\
\text { dari suami. }\end{array}$ \\
\hline 4. & $\begin{array}{lr}\text { Pengetahuan dan } & \text { Dukungan } \\
\text { Suami dengan } & \text { Kejadian } \\
\text { Unmet Need } & \text { Keluarga } \\
\text { Berencana pada } & \text { Pasangan } \\
\text { Usia Subur di } & \text { Wilayah } \\
\text { Puskesmas } & \text { Biromaru } \\
\text { Kabupaten Sigi (19) }\end{array}$ & $\begin{array}{c}\text { Kusika } \\
\text { (2018) }\end{array}$ & $\begin{array}{c}\text { Cross } \\
\text { sectional }\end{array}$ & $\begin{array}{l}\text { WUS yang tidak mendapatkan } \\
\text { dukungan dari suami akan berpeluang } \\
\text { untuk mengalami terjadinya unmet } \\
\text { need KB } 3,2 \text { kali lebih besar } \\
\text { dibandingkan dengan WUS yang } \\
\text { mendapatkan dukungan dari suami }\end{array}$ \\
\hline 5. & $\begin{array}{l}\text { Unmet needs for } \\
\text { contraception: A comparative } \\
\text { study among Somali } \\
\text { immigrant women in Oslo and } \\
\text { their original population in } \\
\text { Mogadishu, Somalia (20) }\end{array}$ & $\begin{array}{c}\text { Gele dan } \\
\text { Qureshi } \\
(2019)\end{array}$ & $\begin{array}{c}\text { Cross } \\
\text { sectional }\end{array}$ & $\begin{array}{l}\text { WUS yang tidak } \\
\text { mengkomunikasikan KB ke suami } \\
\text { akan berpeluang untuk mengalami } \\
\text { terjadinya unmet need KB 2,1 kali } \\
\text { lebih besar dibandingkan dengan } \\
\text { WUS yang mengkomunikasikan KB } \\
\text { ke suami. }\end{array}$ \\
\hline
\end{tabular}




\begin{tabular}{|c|c|c|c|c|}
\hline No & Judul & $\begin{array}{l}\text { Penulis } \\
\text { (Tahun) }\end{array}$ & Metode & Hasil \\
\hline 6. & $\begin{array}{l}\text { The Influence of Husband } \\
\text { Support to the Event of Unmet } \\
\text { Need in the Fertilizer Age in } \\
\text { the Work Area of the } \\
\text { Bangkelekila Community }\end{array}$ & $\begin{array}{l}\text { Pasang dkk } \\
\quad(2020)\end{array}$ & $\begin{array}{c}\text { Cross } \\
\text { Sectional }\end{array}$ & $\begin{array}{l}\text { WPUS yang tidak mendapatkan } \\
\text { dukungan suami berpeluang sebesar } \\
16 \text { kali untuk mengalami unmet need } \\
\text { KB dibanding dengan WPUS yang } \\
\text { mendapat dukungan dari suami. }\end{array}$ \\
\hline
\end{tabular}

7. Unmet need for family planning and its associated factor among women of reproductive age in Debre Berhan Town, Amhara, Ethiopia (22)

8. Analisis Karakteristik Wanita Usia Subur, Dukungan Suami, dan Peran Bidan terhadap Unmet Need Keluarga Berencana di Wilayah Kerja Puskesmas Bungus Kota Padang (13)

Worku, Community Ahmed dan Mulushewa (2019)

Violentina, Yetti, dan Amir (2019)

Puteri, Noor, dan Arifin

(2019) Istri dengan Penggunaan Metode Kontrasepsi Jangka Panjang (MKJP) (23)

10. Analisis Faktor yang Mempengaruhi Kebutuhan Ber-KB dengan Pendekatan Social Cognitive Theory (Studi di Kecamatan Genteng Surabaya) (14)

11. Determinan Unmet Need KB pada Wanita Menikah di Kecamatan Klabang Kabupaten Bondowoso (10)

12. Hubungan Antara Faktor Pengetahuan Istri dan Dukungan Suami terhadap Kejadian Unmet Need KB pada Pasangan Usia Subur di Kelurahan Siantan Tengah Kecamatan Pontianak Utara Tahun 2014 (24)

\section{Ainia (2018) \\ Cross sectional}

Katulistiwa, Baroya, dan Wati (2014)

Wahab, Fitriangga, dan Handini (2014)

\section{Cross}

sectional

Cross

sectional
Case control

WPUS yang tidak mendapatkan dukungan dari suami berpeluang sebesar 100,5 kali untuk mengalami unmet need $\mathrm{KB}$ dibandingkan dengan WUS yang mendapat dukungan suami.

WPUS yang mendapatkan dukungan buruk dari suami berpeluang mengalami kejadian unmet need $\mathrm{KB}$ 16,4 kali lebih besar dibandingkan dengan WUS yang mendapat dukungan baik dari suami.

WUS yang tidak mendapatkan dukungan dari suami akan berpeluang untuk mengalami terjadinya unmet need KB 4,9 kali lebih besar dibandingkan dengan WUS yang mendapatkan dukungan dari suami.

WPUS yang tidak mendapat persetujuan ber-KB dari suami berpeluang 4,9 kali lebih besar mengalami unmet need $\mathrm{KB}$ dibandingkan dengan WPUS yang mendapatkan persetujuan ber-KB dari suami.

WPUS yang kurang mendapatkan dukungan suami berpeluang 39,2 kali lebih besar mengalami unmet need KB dibandingkan dengan WPUS yang mendapatkan dukungan baik dari suami 


\begin{tabular}{llccl}
\hline No & \multicolumn{1}{c}{ Judul } & $\begin{array}{c}\text { Penulis } \\
\text { (Tahun) }\end{array}$ & Metode & Hasil \\
\hline 13. & $\begin{array}{l}\text { Husband's Support towards } \\
\text { Unmet Need of HIV Positive- }\end{array}$ & $\begin{array}{c}\text { Sophia dan } \\
\text { Lestari }\end{array}$ & $\begin{array}{c}\text { Cross } \\
\text { sectional }\end{array}$ & WPUS dengan HIV positif yang tidak \\
Infected mendapatkan dukungan dari suami \\
Childbearing Age (25)
\end{tabular}

\section{PEMBAHASAN}

Terdapat pengaruh antara persepsi suami dengan kejadian unmet need $\mathrm{KB}$ pada PUS. Penolakan suami juga sangat berpengaruh terhadap keputusan penggunaan kontrasepsi. Sebanyak 52\% responden memiliki persepsi yang kurang baik terhadap penggunaan alat kontrasepsi. Kejadian unmet need sering terjadi karena penolakan dari suami untuk menggunakan alat kontrasepsi. Ketidaksetujuan suami terhadap pemakaian alat kontrasepsi dengan alasan karena melihat efek samping seperti terganggunya kesehatan istri setelah memakai alat kontrasepsi dan suami menginginkan anak dengan jenis kelamin yang berbeda dari yang telah mereka punya, selain itu suami menginginkan anak dengan jumlah tertentu sebagai pewaris keturunan juga merupakan alasan meningkatnya kejadian unmet need KB (26).

Pada penelitian Kusika (2018) ditemukan bahwa terdapat hubungan antara dukungan suami dengan kejadian unmet need $\mathrm{KB}$. WUS yang tidak mendapatkan dukungan dari suami akan berpeluang untuk mengalami terjadinya unmet need $\mathrm{KB}$
3,2 kali lebih besar dibandingkan dengan WUS yang mendapatkan dukungan dari suami. Budaya patrilineal yang menjadikan pria sebagai kepala keluarga yang masih banyak dianut sebagian besar pola keluarga di Indonesia, sehingga menjadikan preferensi suami terhadap fertilisasi dan pandangan serta pengetahuannya terhadap program $\mathrm{KB}$ akan sangat berpengaruh terhadap keputusan dalam keluarga untuk menggunakan alat atau metode keluarga berencana tertentu (19).

Pada penelitian Gele dan Qureshi (2019), ditemukan kebutuhan kontrasepsi yang tidak terpenuhi di antara wanita Somalia di Oslo adalah 20,2\%, serupa dengan kebutuhan kontrasepsi wanita yang tidak terpenuhi di banyak negara Afrika sub-Sahara. Sekitar $13,4 \%$ peserta studi di Oslo dan 86,6\% di Mogadishu menganggap kontrasepsi modern tidak relevan bagi kesehatan wanita. Hampir 50\% wanita di kedua tempat tersebut pernah melahirkan tanpa disengaja pada satu atau lebih kesempatan. WUS yang tidak mengkomunikasikan KB ke suami akan berpeluang untuk mengalami terjadinya 
unmet need KB 2,1 kali lebih besar dibandingkan dengan WUS yang mengkomunikasikan KB ke suami (20). Berbeda dengan menurut Moreira dkk (2019), rata-rata $40,9 \%$ wanita yang membutuhkan kontrasepsi tidak menggunakan metode kontrasepsi apa pun untuk menghindari kehamilan. Secara keseluruhan, alasan paling umum untuk tidak menggunakan kontrasepsi adalah "masalah kesehatan" dan "hubungan seks jarang" (27).

Faktor-faktor yang berpengaruh terhadap keputusan penggunaan kontrasepsi berdasarkan Teori Bertrand (1980) pada penelitian Puteri, Noor, \& Arifin (2019) adalah faktor sosiodemografi, faktor sosiopsikologi, dan faktor pelayanan kesehatan. Pada penelitian ditemukan bahwa yang termasuk ke dalam faktor sosiopsikologi adalah dukungan suami dan pola komunikasi suami--istri. WPUS yang mendapatkan dukungan buruk dari suami berpeluang mengalami kejadian unmet need KB 16,4 kali lebih besar dibandingkan dengan WUS yang mendapat dukungan baik dari suami (23).

Peneliti menemukan sebanyak 53,3\% responden mendapatkan dukungan dari suami untuk menggunakan kontrasepsi, serta memiliki pola komunikasi yang baik sebanyak 58,3\%. Peran suami dalam keputusan penggunaan kontrasepsi sangat berpengaruh. Hal itu terjadi karena suami merupakan orang terdekat dari calon akseptor, yaitu istrinya. Seorang istri dapat termotivasi untuk menggunakan kontrasepsi apabila mendapat dukungan dari suaminya. Begitu pula sebaliknya, jika suami tidak mendukung maka penggunaan kontrasepsi akan berkurang. Komunikasi antara suami-istri juga sangat berpengaruh terhadap keputusan penggunaan kontrasepsi. Penentu dalam penggunaan kontrasepsi bisa berdasarkan frekuensi diskusi antara suami-istri $(23,28)$.

Penelitian Katulistiwa, Baroya, dan Wati (2014), menemukan bahwa distribusi unmet sebesar 26\% di Kecamatan Klabang Kabupaten Bondowoso. WPUS yang tidak mendapat persetujuan ber-KB dari suami berpeluang 4,9 kali lebih besar mengalami unmet need $\mathrm{KB}$ dibandingkan dengan WPUS yang mendapatkan persetujuan berKB dari suami. Lebih dari setengah respondennya mendapat tentangan dari suami untuk mengakses pelayanan KB. Namun sebenarnya responden tidak merasa takut atau khawatir untuk menggunakan $\mathrm{KB}$ (10). Wahab, Fitriangga, dan Handini (2014) menemukan sebanyak 52,1\% pasangan usia subur mengalami unmet need KB. Dukungan suami diperlukan agar responden stabil dalam penggunaan kontrasepsi. Istri yang mendapat dukungan suami untuk menggunakan kontrasepsi memang berdasarkan keputusan bersama 
dan sudah memiliki pengetahuan akan pentingnya menggunakan kontrasepsi (24).

Pendidikan (edukasi) mengenai program KB perlu diberikan, sehingga masyarakat tahu mengenai manfaat menggunakan alat kontrasepsi. Masyarakat juga dapat mengetahui dampak atau risiko akibat tidak menunda usia perkawinan, tidak mengatur jarak kehamilan, serta membatasi jumlah anak. Edukasi mengenai program KB diberikan oleh petugas kesehatan berupa konsultasi di tempat pelayanan $\mathrm{KB}$ untuk memberikan informasi mengenai pentingnya menjadi akseptor $\mathrm{KB}$, dengan begitu diharapkan angka kejadian unmet need $\mathrm{KB}$ dapat menurun (19).

\section{KESIMPULAN}

Persetujuan, komunikasi dan dukungan sosial dari suami merupakan faktor utama dalam penggunaan kontrasepsi pada wanita pasangan usia subur (WPUS). Terdapat hubungan antara dukungan suami dengan kejadian unmet need KB. Dukungan positif dari suami dapat meningkatkan penggunaan kontrasepsi, sebaliknya jika suami memberi dukungan negatif dapat menurunkan tingkat penggunaan kontrasepsi. WPUS yang tidak mendapatkan dukungan dari suami berpeluang mengalami unmet need $\mathrm{KB}$ lebih besar dibandingkan dengan WPUS yang mendapat dukungan dari suami.
Saran bagi instansi terkait diharapkan adanya peningkatan pelayanan komunikasi, informasi dan edukasi melalui konsultasi oleh petugas kesehatan kepada para pasangan usia subur khususnya kepada suami mengenai program dan pemanfaatan KB. Bagi masyarakat terutama pasangan usia subur bisa dengan mudah mendapat informasi mengenai program KB di setiap tingkat pelayanan kesehatan sehingga dapat termotivasi untuk menggunakan kontrasepsi serta suami dapat memberi dukungan kepada istri untuk mengikuti program KB. Hal ini berguna untuk menurunkan tingkat unmet need serta meningkatkan kesadaran pasangan usia subur terhadap pentingnya program KB.

\section{DAFTAR PUSTAKA}

1. BPS. Profil Penduduk Indonesia Hasil SUPAS 2015. Jakarta; 2015.

2. BPS. Proyeksi Penduduk Indonesia 2015-2045 Hasil SUPAS 2015. Jakarta; 2020.

3. BKKBN. Rencana Strategis BKKBN 2020-2024. Jakarta; 2020.

4. BPS. Kajian Indikator Sustainable Development Goals (SDGs). Jakarta: Badan Pusat Statistik; 2014.

5. BKKBN. Survei Demografi dan Kesehatan Indonesia (SDKI). Jakarta; 2012. 
6. BKKBN. Survei Demografi dan Kesehatan Indonesia (SDKI). Jakarta; 2017.

7. Manafe D. Angka Kelahiran Naik Buat BKKBN Galau. BERITASATU [Internet]. 2020 [cited 2020 Oct 11]; Available from: https://www.beritasatu.com/kesehatan /599870/angka-kelahiran-naik-buatbkkbn-galau

8. Bradley SEK, Croft TN, Fishel JD. Revising Unmet Need for Family Planning: DHS Analytical Studies 25. Maryland; 2012.

9. BKKBN. Survei Demografi dan Kesehatan Indonesia (SDKI). Jakarta; 2019.

10. Katulistiwa R, Baroya N, Wati DM. Determinan Unmet Need KB Pada Wanita Menikah di Kecamatan Klabang Kabupaten Bondowoso. Pustaka Kesehat. 2014;2(2):277-84.

11. Zia HK. Hubungan Tingkat Pendidikan, Tempat Tinggal dan Informasipetugas Lapangan Keluarga Berencana (PLKB) Terhadap Unmet Need KB Pada Wanita Kawin. Indones J Public Heal. 2019;14(2):150-9.

12. Listyaningsih U, Sumini S, Satiti S. Unmet Need: Konsep Yang Masih Perlu Diperdebatkan. Populasi. 2016;24(1):72-90.

13. Dwi Santi Violentina Y, Yetti H, Amir A. Analisis Karakteristik Wanita Usia
Subur, Dukungan Suami, dan Peran Bidan terhadap Unmet Need Keluarga Berencana di Wilayah Kerja Puskesmas Bungus Kota Padang. J Kesehat Andalas. 2020;8(4).

14. Ainia N. Analisis Faktor yang Memengaruhi Kebutuhan Ber-KB dengan Pendekatan Social Cognitive Theory (Studi di Kecamatan Genteng Surabaya). J Biometrika dan Kependud. 2018;7(1):1.

15. Yuliati LN, Simanjuntak M, Oktriyanto $\mathrm{O}$. The Influence of Information Access, Knowledge, Perception of Family Planning's Risks, and Husband's Support on Interest of Using Contraception for Unmet Need Group. J Ilmu Kel dan Konsum. 2019;12(2):157-68.

16. Wayan AAN, Kadek W. Husband's support towards unmet need family planning incidence on couples of childbearing age in Denpasar city. Int J Res Med Sci. 2020;8(12):4239.

17. Safitri F, Kana I. Determinan Kejadian Unmet Need KB Di Wilayah Kerja Puskesmas Peukan Bada Kabupaten Aceh Besar Tahun 2019. J Healthc Technol Med. 2019;5(2):210.

18. Letamo G, Navaneetham K. Levels, trends and reasons for unmet need for family planning among married women in Botswana: A cross-sectional study. BMJ Open. 2015;5(3):6603. 
19. Kusika SY. Pengetahuan dan Dukungan Suami dengan Kejadian Unmet Need Keluarga Berencana pada Pasangan Usia Subur di Wilayah Puskesmas Biromaru Kabupaten Sigi. J Kesehat Manarang. 2018;4(1):46.

20. Gele AA, Musse FK, Qureshi S. Unmet needs for contraception: A comparative study among Somali immigrant women in Oslo and their original population in Mogadishu, Somalia. PLoS One. 2019;14(8).

21. Pasang ES, Masni M, Jafar N, Stang S, Moedjiono AI, Bustam N. The Influence of Husband Support to the Event of Unmet Need in the Fertilizer Age in the Work Area of the Bangkelekila Community Health Center of North Toraja Regency. Int J Multicult Multireligious Underst. 2020;7(6):549.

22. Worku SA, Ahmed SM, Mulushewa TF. Unmet need for family planning and its associated factor among women of reproductive age in Debre Berhan Town, Amhara, Ethiopia. BMC Res Notes. 2019;12(1):143.

23. Puteri N, Noor M, Arifin S. Hubungan Dukungan Suami dan Pola Komunikasi Suami Istri dengan Penggunaan Metode Kontrasepsi Jangka Panjang (MKJP). Homeostasis. 2019;2(1):147-54.
24. Wahab R, Fitriangga A, Handini M. Hubungan antara Faktor Pengetahuan Istri dan Dukungan Suami Terhadap Kejadian Unmet Need KB pada Pasangan Usia Subur di Kelurahan Siantan Tengah Kecamatan Pontianak Utara Tahun 2014. J Mhs PSPD FK Univ Tanjungpura. 2014;1(1).

25. Sophia, Anwar AD, Lestari BW. Husband's support towards unmet need of HIV positive-infected women of childbearing age. Kesmas. 2016;10(4):156-61.

26. Sariyati S, Mulyaningsih S, Sugiharti S. Faktor yang Berhubungan dengan Terjadinya Unmet Need KB pada Pasangan Usia Subur (PUS) di Kota Yogyakarta. J Ners dan Kebidanan Indones. 2016;3(3):123.

27. Moreira LR, Ewerling F, Barros AJD, Silveira MF. Reasons for nonuse of contraceptive methods by women with demand for contraception not satisfied: An assessment of low and middleincome countries using demographic and health surveys. Reprod Health. 2019;16(1):148.

28. Sumartini S, Indriani D. Pengaruh Keinginan Pasangan Usia Subur (Pus) dalam Penggunaan Metode Kontrasepsi Jangka Panjang. J Biometrika dan Kependud. 2017;5(1):27. 